\title{
DEWEY v. REYNOLDS METALS CO.: LABOR ARBITRATION AND TITLE VII
}

Robert Dewey, an employee of Reynolds Metals Company, refused to work Sunday overtime, as required by the collective bargaining agreement between his union and employer, because his church forbade Sunday labor. After several recorded offenses, Dewey was fired. Believing himself a victim of religious discrimination, Dewey filed a grievance to set in motion the arbitration machinery created by the collective bargaining agreement. After unsuccessful union attempts to conciliate, management and union went to arbitration. Finding that "the agreement does not permit a regular and continuing refusal of all Sunday work on religious grounds," 1 the arbitrator concluded that Dewey's discharge was justified and denied the grievance.

Dissatisfied with the arbitrator's adverse decision, Dewey invoked the procedure of title VII of the Civil Right Act of $1964,{ }^{2}$ prohibiting employment discrimination, by filing a charge with the Equal Employment Opportunity Commission. ${ }^{3}$ Having attempted unsuccessfully to conciliate, ${ }^{4}$ the EEOC notified Dewey of his right to bring suit under title VII in a federal district court within the statutory time limit. ${ }^{5}$

In his complaint Dewey alleged the facts surrounding his contractual grievance and requested reinstatement and back pay for the violation of his title VII rights. Moving to dismiss the complaint, Reynolds Metals argued that by pursuing the grievance-arbitration procedure to finality Dewey had made a binding election of remedies and was thereby barred from bringing suit under title VII. ${ }^{6}$ The district court denied the motion. ${ }^{7}$ On appeal the Sixth Circuit reversed,

1 Dewey v. Reynolds Metals Co., 291 F. Supp. 786, 787 (W.D. Mich. 1968), rev'd, 429 F.2d 324 (6th Cir. 1970), cert. granted, 400 U.S. 1008 (1971).

242 U.S.C. $\$ \S 2000$ e to e-15 (1964). Section 703(a), 42 U.S.C. $\$ 2000 \mathrm{e}-2$ (a) (1964), provides:

It shall be an unlawful employment practice for an employer-

(1) to fail or refuse to hire or to discharge any individual, or otherwise to discriminate against any individual with respect to his compensation, terms, conditions, or privileges of employment, because of such individual's race, color, religion, sex, or national origin; or

(2) to limit, segregate, or classify his employees in any way which would deprive or tend to deprive any individual of employment opportunities or otherwise adversely affect his status as an employee, because of such individual's race, color, religion, sex, or national origin.

Section 703(c) (2), 42 U.S.C. $\$ 2000 \mathrm{e}-2$ (c) (2) (1964), makes a prohibition similar to $\$ 703$ (a) (2) applicable to unions, while $\$ 703$ (c) (3), 42 U.S.C. $\$ 2000 \mathrm{e}-2$ (c) (3) (1964), forbids a union "to cause or attempt to cause an employer to discriminate against an individual in violation of this section."

3 See 42 U.S.C. $\$ 2000$ e-5(a). The ninety day statute of limitations for such charges, id. $\$ 2000 \mathrm{e}-5$ (d), was held tolled while the plaintiff attempted private settlement in Culpepper v. Reynolds Metals Co., 421 F.2d 888 (5th Cir. 1970).

4 See 42 U.S.C. $\$ 2000$ e-5 (a) (1964).

5 See id. $\$ 2000 \mathrm{e}-5(\mathrm{e})$.

6291 F. Supp. 786 (W.D. Mich. 1968).

7 Id. at 790 . 
holding that the suit should have been dismissed because union and management had agreed to be bound by the arbitrator's decision and because permitting Dewey recourse from adverse arbitration would undermine the federal policy of encouraging private settlement of labor disputes. ${ }^{8}$

This Comment analyzes the election of remedies doctrine and its application by the Dewey courts, and suggests that the actual policy considerations involved do not justify any rule barring federal suits involving alleged employment discrimination on the ground that arbitration has been invoked or pursued to finality.

\section{The Election of Remedies Doctrine}

The election of remedies doctrine, rarely invoked unless a party is attempting to pursue a remedy inconsistent with one already pursued, ${ }^{9}$ has been variously applied by federal courts in title VII cases. ${ }^{10}$ The state courts have spoken more precisely of the rule:

The doctrine of election of remedies is [based] . . . upon the theory that a party cannot in the assertion of his right occupy inconsistent positions in relation to the facts which form the basis of his respective remedies; it is based on the proposition that, when a party has two remedies proceeding upon opposite and inconsistent claims of right, the one adopted excludes the other. ${ }^{11}$

In fact, the doctrine does not relate to inconsistent remedies at all.

[It] is not an inconsistency between the remedies themselves . . . but it means that a certain state of facts relied upon as the basis of a certain remedy is inconsistent with and repugnant to another certain state of facts relied upon as the basis of another remedy. ${ }^{12}$

Thus, in Estate Counseling Service, Inc. v. Merrill Lynch, Pierce, Fenner and Smith, Inc., ${ }^{13}$ in which the plaintiff had purchased stock

8429 F.2d 324 (6th Cir. 1970), cert. granted, 400 U.S. 1008 (1971). In addition, the court held that the employer's action did not violate title VII. This Comment, however, deals only with the election issue.

3 Comment, 44 N.Y.U.L. REv. 404, 406 (1969).

10 Compare Edwards v. North Am. Rockwell Corp., 291 F. Supp. 199 (C.D. Cal. 1968), and Washington v. Aerojet-General Corp., 282 F. Supp. 517 (C.D. Cal. 1968), with Bowe v. Colgate-Palmolive Co., 272 F. Supp. 332 (S.D. Ind. 1967), rev'd, 416 F.2d 711 (7th Cir. 1969). In Bowe the court permitted a title VII suit after arbitration, but held that upon judgment in the district court the employee must choose between the two remedies. In Hutchings v. United States Industries, Inc., 428 F.2d 303 (5th Cir. 1970), on the other hand, the Fifth Circuit held that a title VII suit alleging racial discrimination in job promotion should not have been dismissed although commenced twenty months after the arbitrator had denied the employee's grievance.

11 McMahon v. McMahon, 122 S.C. 336, 341, 115 S.E. 293, $294-95$ (1922).

12 Id.

13303 F.2d 527 (10th Cir. 1962). 
through the defendant broker and later refused to pay the margin deposit, the Tenth Circuit held that by sending the defendant a "formal demand for rescission," the plaintiff had elected his remedy and was barred from later suing for damages for alleged fraud. The court reasoned that plaintiff had two alternative, inconsistent remedies, because the damage suit "counts upon the affirmance or validity of the transaction, [while rescission] repudiates the transaction and counts upon its invalidity." 14 "[T] he choice of one rejects the other, because the sale cannot be valid and void at the same time." 15

As the Estate Counseling court demonstrates, the rationale behind the election doctrine is not a general apprehension that plaintiff will recover twice, ${ }^{16}$ but a specific refusal to permit plaintiffs to affirm the existence of one set of facts entitling them to relief and later to disaffirm that set and assume a contrary set of facts entitling them to a different remedy.

In the typical grievance-arbitration situation, however, this doctrine is inapplicable. In arbitration the employee claims violation of a contractual right. In a title VII suit he urges that his statutory right to be free from discrimination has been infringed. That in each instance he attempts to vindicate a right violated by the same impermissible conduct should not invoke the election doctrine, since that doctrine rests not on the similarity of the rights asserted, but on inconsistent factual allegations and, thus, necessarily exclusive remedies. Here, by contrast, there is no necessary inference that the two are intended to be alternatively asserted.

The plaintiff employee's rights differ not merely with respect to the sources by which they are conferred, private agreement and federal statute, but more fundamentally with respect to the purposes they serve, the procedures governing their consideration, and the remedies available for their enforcement in each forum. When the employee claims a violation of a right conferred by the collective bargaining agreement, the arbitrator's function is to examine the agreement between union and management and resolve the dispute in accordance with what he

$14 I d$. at 531 .

15 Id., see United States v. Oregon Lumber Co., 260 U.S. 290, $294-95$ (1922) :

[P] laintiff in error was entitled either to disaffirm [the sale] and recover

the lands or afirm it and recover damages for the fraud. It could not do both.

Both remedies were appropriate to the facts, but they were inconsistent since the first was founded upon a disaffirmance and the second upon an affirmance [of the transaction] ....

16 But see Comment, 44 N.Y.U.L. Rev. 404, 406 (1969). In Bowe v. ColgatePalmolive Co., 416 F.2d 711 (7th Cir. 1969), the court expressed concern about the duplicate relief problem, and, on that basis, required an "election . . after adjudication so as to preclude ... [a] windfall to the plaintiffs." Id. at 715. This solution is unsatisfactory since, as the Bowe court itself recognized, the contract remedy may be inadequate under the statutory standard and vice versa. Id. Compare Fleming, Arbitrators and the Remedy Power, 48 VA. L. REv. 1199 (1962), with 42 U.S.C. $\$ 2000 \mathrm{e}-5$ (g) (1964). So long as the two awards taken together give the employee no more than his just due in terms of both contractual and statutory standards, he recovers no windfall; to the extent enforcement of both awards is redundant or duplicative, the court can make adjustment. 
determines to have been their intent. ${ }^{17}$ Although the agreement may be given meaning by past shop practices ${ }^{18}$ or by an understanding between the parties not reduced to writing, "his award is legitimate only so long as it draws its essence from the collective bargaining agreement." 19 An award "based solely upon the arbitrator's view of the requirements of enacted legislation . . . would mean that he exceeded the scope of the submission." 20

Because it serves only this limited purpose, a collective bargaining agreement may provide no protection against discrimination as such. In Dewey, for example, employees were required under the contract to accept Sunday overtime work unless they had a "substantial and justifiable reason for not working." 21 The arbitrator, whose authority was limited by a clause stating that

[t] he arbitrator shall have authority to interpret this Agreement for the purpose of settling the grievance but he shall have no authority to add or to detract from or change this Agreement, $^{22}$

had to determine whether Dewey's religious beliefs were a "substantial and justifiable" excuse under the contract, not whether his title VII rights had been violated.

Further, even if the arbitrator had decided that a religious belief does constitute a "substantial and justifiable" reason, any conformity with title VII standards would be sheer coincidence.

The instinct, self-interest and the training of the arbitrator as well as the body of law surrounding his work, all call out for him to accept that position which will secure the assent

17 "Intent" in this context may, of course, mean that the arbitrator effectuates what the parties would have done had they considered the specific situation. See Cox, The Legal Nature of Collective Bargaining Agreements, 57 MICH. L. Rev. 1 (1958).

${ }^{18}$ As to whether the employer is subject to restrictions not contained in the collective bargaining agreement, see Cox, Reflections upon Labor Arbitration, 72 HARv. L. REv. 1482, 1499 (1959); Mittenthal, Past Practice and the Administration of Collective Bargaining Agreements, 59 MICH. L. REv. 1017, 1026-40 (1961). Compare, e.g., Fruehauf Trailer Co., 29 Lab. Arb. 372 (1957) (yes), with, e.g., National Distillers Products Corp., 24 Lab. Arb. 500 (1953) (no).

19 United Steelworkers v. Enterprise Wheel \& Car Corp., 363 U.S. 593, 597 (1960). Courts have differed over whether the arbitrator may consider legal or public policy. See Black v. Cutter Laboratories, 43 Ca1. 2d 788, 278 P.2d 905 (1955), cert. dismissed as improvidently granted, 351 U.S. 292 (1956). Compare Avco Corp. v. Preteska, 174 A.2d 684 (Conn. Super. Ct. 1961) (award ordering reinstatement of gambler vacated as against public policy), with Local 453, Elec., Radio \& Mach. Workers v. Otis Elevator Co., 314 F.2d 25 (2d Cir. 1963) (gambling; opposite result). (1960).

20 United Steelworkers v. Enterprise Wheel \& Car Corp., 363 U.S. 593, 597

21 Dewey v. Reynolds Metals Co., 429 F.2d 324, 328 (6th Cir. 1970).

22 Collective Bargaining Agreement between Reynolds Metals $C_{0}$. and UAW Local 27, Art. XI, $\$ 2$, Step 5, in Supplemental Brief for Appellee, at 8, Dewey v. Reynolds Metals Co., 429 F. 2d 324 (6th Cir. 1970). 
of both of [sic] union and management. Union and management want him to operate within the framework of contractual principles which they have established, rather than range over their relationship with a roving commission to implement federal legislative policy. ${ }^{23}$

A potentially more difficult situation arises when the collective bargaining agreement itself contains an antidiscrimination clause. ${ }^{24}$ An arbitrator's decision that the employer has violated a contractual duty at least as stringent as the duty imposed by title VII, however, still provides no basis for applying an election doctrine when the employee later goes to court for an additional remedy. Although his determination may include consideration of title VII on the theory that "[s] ince the parties themselves have used title VII of the Act as a model, Enterprise Wheel teaches that an arbitrator's award which looks to the Act in . . . resolving the current contract issue is an appropriate one," ${ }^{25}$ he will still be bound to interpret the antidiscrimination clause in light of what the parties intended. Notwithstanding his consideration of title VII and any expertise developed from arbitrating previous disputes involving antidiscrimination clauses, " $[t]$ he arbitrator does not necessarily have special training in law-let alone an expertise in the fast moving complexities of labor and civil rights law." 28 To the extent, then, that judicial precedents and legal analysis are important, the federal judge can more adequately protect title VII rights.

Not only does the arbitrator pursue a different and more limited goal than the federal court, but many procedural safeguards available to the civil plaintiff, such as discovery and cross-examination of witnesses, may not be available under the collective bargaining agreement. ${ }^{27}$ The district court in Dewey noted that

[t] his reasoning is especially justified in this case, where the employee was not represented by counsel at the arbitration hearing, although the company was; and where the union did

23 Blumrosen, Labor Arbitration, EEOC Conciliation, and Discrimination in Employment, 24 ARB. J. (n.s.) 88, 94 (1969).

24 See Platt, The Relationship between Arbitration and Title VII of the Civil Rights Act of 1964, 3 GA. L. Rev. 398, 400-01 \& nn. 16-18 (1969).

$25 I d .402$.

26 Gould, Labor Arbitration of Grievances Involving Racial Discrimination, 118 U. PA. I. Rev. 40, 48 (1969). The arbitrator's role requires many of the qualities demanded of judges-expertise in analyzing issues, in weighing evidence, and in interpreting contracts. Judge Hays has, though, suggested that arbitrators have little expertise. Hays, The Future of Labor Arbitration, 74 Y ALE L.J. 1019 (1965). Moreover, he says, "[A] system of adjudication in which the judge [or arbitrator] depends for his livelihood ... on pleasing those who hire him to judge is per se a thoroughly undesirable system." Id. 1035. But see Aaron, Judicial Intervention in Labor Arbitration, 20 STAN. L. REv. 41, 51 (1967).

27 See, e.g., R. Smith, L. Merrifield, \& D. Rothschim, Collective Bargaining aNd LaboR ARBitration 210-13 (1970). 
not file a brief on behalf of the employee though the company filed a brief on its behalf. ${ }^{28}$

Finally, the arbitration process differs from federal court determination with respect to remedies. Here also the arbitrator takes his authority to remedy violations from the collective bargaining agreement. ${ }^{29}$ While the arbitrator may have the power to fashion wide ranging remedies, such as an "injunction" against a work slowdown, ${ }^{30}$ a federal judge implementing title VII will have power beyond settlement of the contract dispute. The Fifth Circuit, in Local 53, Heat and Frost Insulators v. Vogler, ${ }^{31}$ for instance, held that the Act grants to a district court "a large measure of discretion in modeling its decree to ensure compliance with the Act . . . ." 32 "Where necessary .. . the District Court was fully empowered to eliminate the present effects of past discrimination." 33 Relief protecting all employees against discrimination, rather than merely settling a contract grievance, furthers title VII policy. When permitted to take "the mantel of the sovereign" ${ }^{34}$ as a private attorney general, the plaintiff helps to further the national policy of eliminating employment discrimination. ${ }^{35}$ To the extent that a collective bargaining agreement and the need to resolve a dispute do not dictate such relief, the employee can hardly be said to have in arbitration an alternative remedy to title VII. The rights conferred by title VII and collective bargaining agreements, thus, differ in their sources, purposes, enforcement procedures, and remedies. There is no inconsistency in holding such actions mutually complementary and in such a case the doctrine of election of remedies should have no application.

\section{Title VII and Arbitration of Grievances Alleging Discrimination}

Both the district court and the court of appeals in Dervey appear to have been concerned not with the election of remedies doctrine as

28291 F. Supp. at 789. (1960).

29 United Steelworkers v. Enterprise Wheel \& Car Corp., 363 U.S. 593, 597

30 See Fleming, Arbitrators and the Remedy Power, 48 VA. L. REv. 1199, 1221-22 (1962). Professor Gould feels that "the acceptability of these decisions is attributable to the fact that they are in accord with the parties' conscious and subconscious ex-. pectations." Gould, supra note 26, at 48-49.

31407 F.2d 1047 (5th Cir. 1969).

$32 I d$. at 1052 .

33 Id. at 1052-53.

34 Jenkins v. United Gas Corp., 400 F.2d 28, 32 (5th Cir. 1968).

35 See Hutchings v. United States Indus., Inc., 428 F.2d 303, 311 (5th Cir. 1970) ("proceeding takes on a public character"). One commentator asserted that "[t]he inner logic and structure of Title VII is directed primarily not to the protection of private rights but to the protection of the public interest in the elimination of all discriminatory employment practices." Affeldt, Title VII in the Federal Courts-Private or Public Law, Part I, 14 Vul. L. REv. 664, 676 (1969). But cf. Developments in the Law-Employment Discrimination and Title VII of the Civil Rights Act of 1964, 84 HARv. L. REv. 1109, 1224-25 (1971). 
it is usually applied, but with an "election of forum" problem. The district court used the terms interchangeably ${ }^{36}$ and although the court of appeals did not mention election of remedies, Circuit Judge Combs, dissenting, rejected the choice put the plaintiff calling it an application of the election of remedies doctrine. ${ }^{37}$ Perhaps not content to rest on their decisions on the applicability of the election of remedies doctrine, both Dewey courts found policy reasons to support their opposing results. Each court, thus, implicitly recognized that the election issue in title VII cases is finally resolved in terms of policy-here federal policy, because the choice to be made involves a clash not between federal intervention and private settlement, but between federal civil rights policy and federal labor policy.

In the labor relations field, the arbitrator's role is extremely important. The Steelworker's Trilogy ${ }^{38}$ expressed the federal policy of granting the arbitrator a maximum role as a means of maintaining industrial peace. "Arbitration is the means of solving the unforeseeable by molding a system of private law for all the problems which may arise and to provide for their solution in a way which will generally accord with the variant needs and desires of the parties." 39 To achieve this end, judicial review of an arbitrator's decision is limited..$^{40}$

Eliminating job discrimination is also a national policy. In title VII, Congress created a statutory right and remedy separate and distinct from any conferred by private agreement. ${ }^{41}$ When an employee brings a title VII suit, alleging a violation of his federal statutory right, he is "vindicating a policy that Congress considered of the highest priority." 42

The Dewey district court, while misconstruing the election doctrine, ${ }^{43}$ rejected the employer's argument for policy reasons rather than the substantive inapplicability of the doctrine:

To hold otherwise would be to require the employee to have come to this court without attempting a settlement through

36 See 291 F. Supp. at 788.

37429 F.2d at 334.

38 United Steelworkers v. American Mfg. Co., 363 U.S. 564 (1960) ; United Steelworkers v. Warrior \& Gulf Navigation Co., 363 U.S. 574 (1960) ; United Steelworkers v. Enterprise Wheel \& Car Corp., 363 U.S. 593 (1960). (1960).

39 United Steelworkers v. Warrior \& Gulf Navigation Corp., 363 U.S. 574, 581

40 United Steelworkers v. Enterprise Wheel \& Car Corp., 363 U.S. 593 (1960).

41 Hutchings v. United States Indus., Inc., 428 F.2d 303 (5th Cir. 1970) ; see King v. Georgia Power Co., 295 F. Supp. 943 (N.D. Ga. 1968) ; Reese v. Atlantic Steel Co., 282 F. Supp. 905 (N.D. Ga. 1967) ; Comment, 44 N.Y.U.L. REv. 404, 407 (1969).

42 Newman v. Piggie Park Enterprises, Inc., 390 U.S. 400, 402 (1968). While the Court was referring to title II of the Civil Rights Act of 1964,42 U.S.C. $\$ \S 2000$ a to $a-6(1964)$, its logic was applied to title VII in Oatis v. Crown Zellerbach Corp., 398 F.2d 496, 499 (5th Cir. 1968).

43 "The doctrine . . . has been traditionally applied in cases where the same or nearly identical issues were being pursued in two forums." $291 \mathrm{~F}$. Supp. at 788. 
the contractual processes, as preferred by the national labor law. Plaintiff would also have been required to choose between two different remedies when both remedies are provided to insure that plaintiff's contractual, statutory and constitutional rights are protected. ${ }^{44}$

On appeal, the Sixth Circuit based its reversal on policy grounds. First, concerned with the unilateral relief of title VII, the court found that because the parties had given their "consent" to arbitration, the arbitrator had a "right" to finally determine the grievance based on alleged discrimination. ${ }^{45}$ Secondly, the court found policy justification in the effects federal relief would otherwise have on the arbitral process:

[Permitting the employee to sue after arbitration] would sound the death knell to arbitration of labor disputes . . . . Employers would not be inclined to agree to arbitration clauses . . . if they provide only a one-way street, i.e., that the awards are binding on them but not on their employees. ${ }^{46}$

Finally, the court found no "national policy" favoring the opposite result. ${ }^{47}$

Thus, the district court and the court of appeals in Dervey disagreed not so much on the substantive applicability of a legal doctrine, as on policy considerations: the effect which a title VII suit would have on the arbitral process and national labor policy. The Sixth Circuit's analysis is not persuasive.

The first objection of the court of appeals arose from its concern for the employer's plight as the only party bound by arbitration. ${ }^{48}$ The court based its argument on two complementary premises: (a) the employer, but not the employee, would be bound by arbitration; and (b) the employee could, thus, force the employer to defend the same action twice. ${ }^{49}$

Although an appeal to fairness, ${ }^{50}$ the first premise is unpersuasive. The notion appears to be that in the absence of mandatory election,

44 Id. at 789 .

45429 F.2d at 332 .

$46 I d$.

47 Id.

$48 I d$. at 332,337 .

49 These are separate considerations when the arbitrator has not yet decided the grievance. See Bowe v. Colgate-Palmolive Co., 272 F. Supp. 332, 366-67 (S.D. Ind. 1967), rev'd, 416 F.2d 711 (7th Cir. 1969).

50 Any appeal to fairness must also recognize that forcing an election, although eliminating apparent unfairness to the employer, may be unfair to the employees whom Congress sought to protect under title VII. Under the doctrine of Vaca v. Sipes, 386 U.S. 171 (1967), the union has wide control over the processing and settlement of employee grievances subject only to the duty of fair representation. Since the employee may on impulse use the more familiar grievance machinery and place the care of his rights in the union's custody, if later dissatisfied with the union's treatment of his grievance, he will be barred from enforcing his title VII rights in court. This unfairness would naturally follow from a combination of $V a c a$ and Dewey. See Gould, supra note 26 , at 56 . 
the employee will be permitted to "appeal" from arbitration adverse to him, while the employer will be bound subject to a limited right to appeal from the arbitrator's decision as violative of the contract. ${ }^{51}$ This argument ignores the fact that the employee is not "appealing" the arbitrator's decision, but is pursuing a judicially enforced remedy for violation of his statutory right. ${ }^{52}$ Any apparent unfairness to the employer should be irrelevant, since Congress did not choose to give the employer this statutory remedy. ${ }^{53}$

The other premise of the argument, that the employer must defend the same action twice, is also unpersuasive. If Congress intended title VII to provide a separate and distinct right and remedy, it must equally have assumed that a national policy of eliminating job discrimination is worth the price the employer must pay in terms of inconvenience. The jurisdiction of the National Labor Relations Board to hear unfair labor practice charges arising from incidents concurrently the subject of grievance arbitration has been claimed equally burdensome. ${ }^{54}$ But while the Board has what might be called a specific exemption from the election doctrine, ${ }^{55}$ the employer is not unduly inconvenienced by double prosecution, and the courts have held in this situation that two specific rights are involved. ${ }^{56}$

Supporting this refusal to provide a title VII "appeal" to the employee alone, the Dewey court maintained that the employee is bound because the union and the employer have consented to arbitration's "final and binding" effect. 57 But even though the union does have extensive authority to concede employee rights in return for employer concessions, ${ }^{58}$ it has no power to limit the employee's right to sue under title VII. ${ }^{59}$ To construe the "final and binding" clause

51 Labor Management Relations Act, 1947, §301, 29 U.S.C. $\$ 185$ (1964). See, e.g., Torrington Co. v. Local 1645, UAW, 362 F.2d 677 (2d Cir. 1966).

52 See note 42 supra; Gould, supra note 26, at 57.

53 Congress could reasonably have found the incidence of employee discrimination against employers so small as not to warrant a coextensive right.

The concern . . . that the defendant does not enjoy the right to proceed to court following an adverse ruling by an arbitrator... flows from the fact the employer cannot as a matter of law be the victim of discrimination by an employee. The law was intended to benefit employees, and, thus, it is the employee as the alleged discriminatee whom the statute and the courts have given dual avenues to relief.

Supplemental Brief of EEOC as Amicus Curiae at 9 n.2, Dewey v. Reynolds Metals Co., 429 F.2d 324 (6th Cir. 1970).

54 See Carey v. Westinghouse Elec. Corp., 375 U.S. 261 (1964); Smith v. Evening News Ass'n, 371 U.S. 195 (1962).

55 National Labor Relations Act $\$ 10$ (a), 29 U.S.C. $\$ 160$ (a) (1964).

50 United Steelworkers v. American Int'l Aluminum Corp., 334 F.2d 147, 152 (5th Cir. 1964).

57429 F.2d at 332, 337.

58 See, e.g., Armco Steel Corp. v. NLRB, 344 F.2d 621 (6th Cir. 1965).

59 "No labor organization shall limit the right of any member thereof to institute an action in any court . . . irrespective of whether or not the labor organization or its officers are named as defendants. " Labor-Management Reporting and Disclosure Act of $1959 \S 101$ (a) (4), 29 U. S.C. $\$ 411$ (a) (4) (1964). Any union agreement, enforceable by a court, that the employee will not sue after the arbitrator's decision limits his title right to bring a federal suit. 
as limiting the employee's right to sue fails to recognize that the union's consent can only make the arbitrator's decision "final and binding" on issues arising under the collective bargaining agreement.

The second major objection of the Dewey court, fear that failure to apply the election of remedies doctrine would damage the incentive to arbitrate, ${ }^{60}$ is also baseless. To the employer as well as the employee arbitration has intrinsic virtues, such as the relatively swift and inexpensive resolution of disputes. The Sixth Circuit's concern that employers may attempt to eliminate arbitration clauses altogether ${ }^{61}$ is misplaced. Even if an employer were willing to forego the benefits of arbitration of title VII claims, he would be unlikely to desire the elimination of the entire arbitration process, since to him arbitration remains attractive for settling other disputes.

An employer might, however, attempt to carve out of the arbitrator's jurisdiction an exception for title VII grievances. But this possibility is remote. First, the employer may still desire to arbitrate these disputes because settlement satisfactory to both sides may result and thus save him the expense, adverse publicity, and aggravation of defending in federal court. More importantly, Congress by passing title VII clearly established that job discrimination is unlawful. Even if permitting federal suit discourages arbitration, this does not justify forcing the employee to choose between forums. Congress could have attempted to satisfy both policies, encouraging arbitration and eliminating discrimination, by declaring the national policy against discrimination and by requiring all labor arbitrators to read into collective bargaining agreements the law of the land. It did not choose to do so. To give greater weight to the policy of encouraging arbitration at the expense of the statutory policy of eliminating discrimination is to impute to Congress an intention not revealed in title VII. On the other hand, permitting federal suit does not necessarily discourage arbitration. It merely places in the hands of the federal courts the ultimate power to enforce rights if they are not adequately enforced elsewhere.

From the other side, the employee's incentive to arbitrate grievances alleging job discrimination will not be diminished by permitting a title VII suit. To the employee arbitration remains attractive-to the degree it is fair-because it is less formal and costly than a civil suit. If he does have some preference to arbitrate, as may be instinctual with many workers, or at least desires to retain his options, the employee will still grieve promptly to prevent forfeiture of his rights under the collective bargaining agreement's time limits. ${ }^{62}$ If permitted to pursue

60429 F.2d at 332 .

61429 F.2d at 332 .

62 See, e.g., Collective Bargaining Agreement between Brooklyn Union Gas Co. and Local 101, TWU, Apr. 1, 1968, Art. VII, Grievance Procedure § 1, in CCH LAB. L. Rep. (Union Contracts-Ârbitration) $\llbracket 59,911$, at 85,356: An employee shall cause his grievance to be submitted to his immediate supervisor within fourteen (14) days 
contractual and statutory remedies simultaneously, the employee still has an incentive to attempt arbitration, because victory there may enable him to terminate his title VII suit. Thus, even in the absence of the election doctrine employees will only gain by trying the arbitration method of settlement.

On the other hand, applying the election doctrine practically eliminates the employee's incentive to arbitrate. When advised that the arbitrator's decision will foreclose pursuit of his title VII remedies, he may conclude that the cost and trouble of instituting a civil suit are justified by the greater possibility of ultimate success. ${ }^{63}$ Although he may bypass arbitration when his chances of winning there on a valid claim are slight, as for instance when the terms of the contract create or condone discrimination, ${ }^{64}$ national labor policy should not give binding effect to grievances vainly pursued. ${ }^{65}$ Moreover, the need for an independent body to resolve the dispute is most compelling in such a case because the employee may be protesting a pattern of discrimination which affronts public standards and national policy to a palpably greater degree than an isolated discriminatory incident.

\section{CONCLUSION}

The election of remedies doctrine, or any doctrine barring an employee from commencing a title VII suit because of prior or pending arbitration, should have no effect on an employee's title VII rights and remedies. First, that doctrine applies only when the employee maintains inconsistent positions in pursuit of inconsistent and possibly duplicative remedies. Second, because title VII provides rights and remedies distinct and in addition to any conferred by private agreement, "[p]ublic policy requires that the power to remedy unlawful employment practices not be abdicated to another forum." 66 Third, permitting an employee to pursue his remedies in court after arbitration is not likely to damage the national policy of encouraging arbitration, but forcing an employee to choose between forums may thwart Congress's policy of eliminating job discrimination.

after occurrence of the events giving rise to the grievance. $C f$. Wallace v. Southern Pac. Co., 106 F. Supp. 742 (N.D. Cal. 1951) (discharged employee who failed to present grievance within time prescribed in contract forfeits recovery for loss of employment). Even when the contract does not specify the time within which a grievance must be filed, a reasonable period becomes the standard. Local 205, Elec., Radio \& Mach. Workers v. General Elec. Co., 172 F. Supp. 53 (D. Mass. 1959). 63 Cf. Dewey v. Reynolds Metals Co., 291 F. Supp. 786, 789 (W.D. Mich. 1968). 64 See, e.g., Local 53, Heat \& Frost Instulators v. Vogler, 407 F.2d 1047 (5th Cir. 1969) (discriminatory union membership provision); Quarles v. Philip Morris, Inc., 279 F. Supp. 505 (E.D. Va. 1968) (de facto discrimination).

${ }^{65}$ Cf. Glover v. St. Louis-S.F. Ry., 393 U.S. 324 (1969) (concerted unionmanagement discrimination), in which the Court articulated an exception to the rule of Republic Steel Corp. v. Maddox, 379 U.S. 650 (1965), which required an employee to exhaust his contractual remedies before seeking judicial review of his contract claim. The Court said "the effort to proceed formally with contractual or administrative remedies would be wholly futile." 393 U.S. at 330.

66 Gould, sipra note 26 , at 58 . 
Permitting the plaintiff employee to pursue both arbitration and federal suit simultaneously only until one is completed ${ }^{67}$ is unsatisfactory, because the employee may have no control over timing these decisions and cannot weigh the adequacy of either award until a decision is announced. ${ }^{68}$ Although this problem can be overcome by allowing the plaintiff to pursue both proceedings to completion, the one court adopting this policy has, in addition, forced the employee to choose between the awards granted. ${ }^{69}$ When the arbitrator has found discrimination and has made an award, the employee should not be forced to choose between what may be complementary awards; instead, each award should be tailored to the purpose for which it is intended and the later decision should eliminate any duplication.

The correct disposition would permit the employee to institute a title VII suit at any time. Such disposition will further both national goals involved-the use of arbitration to settle labor disputes and the effective elimination of job discrimination.

67 Washington v. Aerojet-General Corp., 282 F. Supp. 517 (C.D. Cal. 1968).

68 Gould, supra note 26 , at 58.

69 Bowe v. Colgate-Palmolive Co., 416 F.2d 711 (7th Cir. 1969). 